\title{
UTILIZATION OF NITROGEN FROM GREEN MANURE AND MINERAL FERTILIZER BY SUGARCANE
}

\author{
Edmilson José Ambrosano ${ }^{1 *}$; Paulo Cesar Ocheuze Trivelin²; Heitor Cantarella ${ }^{3}$; Gláucia Maria \\ Bovi Ambrosano ${ }^{4}$; Eliana Aparecida Schammass ${ }^{5}$; Nivaldo Guirado ${ }^{1}$; Fabrício Rossi ${ }^{1}$; Paulo \\ Cesar Doimo Mendes ${ }^{1}$; Takashi Muraoka ${ }^{6}$ \\ ${ }_{2}^{1}$ Apta/IAC - Pólo Regional Centro Sul, DDD/Apta, C.P. 28 - 13400-970 - Piracicaba, SP - Brasil. \\ ${ }^{2}$ USP/CENA - Lab. de Isótopos Estáveis, Divisão de Desenvolvimento de Métodos e Técnicas Analíticas e Nucleares, \\ C.P. 96 - 13400-970 - Piracicaba, SP - Brasil. \\ ${ }_{4}^{3}$ Apta/IAC - Centro de Solos e Recursos Agroambientais, C.P. 28 - 13001-970 - Campinas, SP - Brasil. \\ ${ }_{5}^{4}$ UNICAMP/FOP - Depto. de Odontologia Social, Bioestatistica, C.P. 52 - 13414-903 - Piracicaba, SP - Brasil. \\ ${ }^{5}$ Instituto de Zootecnia, Bioestatística, R. Heitor Penteado, 56 - 13460-000 - Nova Odessa, SP - Brasil. \\ ${ }^{6}$ USP/CENA - Lab. de Fertilidade do Solo, Divisão de Produção Agroindustrial, C.P. 96 - 13400-970 - Piracicaba, \\ SP - Brasil. \\ *Corresponding author <ambrosano@aptaregional.sp.gov.br>
}

ABSTRACT: Given their potential for biological nitrogen fixation, legumes used as green manure are an alternative source of nitrogen to crops, and can supplement or even replace mineral nitrogen fertilization. The utilization of nitrogen by sugarcane (Saccharum spp.) fertilized with sunn hemp (Crotalaria juncea L.) and ammonium sulphate (AS) was evaluated using the ${ }^{15} \mathrm{~N}$ tracer technique. Amounts of $195.8 \mathrm{~kg}$ and $70 \mathrm{~kg} \mathrm{~N}$ per hectare, respectively, of sunn hemp and AS were added in the following treatments: without green manure and without AS; without green manure, with AS $-{ }^{15} \mathrm{~N}$; with green manure- ${ }^{15} \mathrm{~N}$ and with $\mathrm{AS}$; with green manure- ${ }^{15} \mathrm{~N}$, without AS; with green manure and with $\mathrm{AS}^{-15} \mathrm{~N}$. Four samples from the leaves +3 were collected and $2 \mathrm{~m}$ of the sugar cane row were harvested to estimate crop yield. The results for $\mathrm{N}$ contents $\left(\mathrm{g} \mathrm{kg}^{-1}\right)$, isotopic abundance of $\mathrm{N}\left(\right.$ atoms $\left.\%{ }^{15} \mathrm{~N}\right)$ in leaf +3 samples, and sugarcane productivity were used to calculate cumulative $\mathrm{N}$, nitrogen in the plant derived from the fertilizer-Ndff $\left(\%\right.$ and $\left.\mathrm{kg} \mathrm{ha}^{-1}\right)$, as well as percent recovery of fertilizer $\mathrm{N}(\mathrm{R} \%)$. Sugarcane was analysed and pol and total recovered sugar calculated. The highest Ndff percentages were observed eight months after sugarcane planting for treatments containing green manure without mineral $\mathrm{N}$, and green manure with mineral $\mathrm{N}$, at 15.3 and $18.4 \%$, respectively. The best nitrogen recovery was observed during harvest, 18 months after planting; the treatment containing mineral fertilizer showed $34.4 \%$ recovery, while the sum between mineral $\mathrm{N}$ plus green manure $\mathrm{N}$ showed $40.0 \%$. Treatments containing green manure plus mineral $\mathrm{N}$ changed soil attributes, by increasing $\mathrm{Ca}$ and $\mathrm{Mg}$ contents, sum of bases, $\mathrm{pH}$, and base saturation, and decreasing potential acidity. In the plant, those treatments increased $\mathrm{Ca}$ and $\mathrm{K}$ contents.

Key words: Saccharum spp., sunn hemp, ${ }^{15} \mathrm{~N}$, isotope technique

\section{APROVEITAMENTO DO NITROGÊNIO DA ADUBAÇÃO VERDE E DA FERTILIZAÇÃO MINERAL PELA CANA-DE-AÇÚCAR}

RESUMO: Em função de seu potencial de fixação de nitrogênio, as leguminosas adubos verdes representam uma alternativa ao suprimento, substituição ou complementação da adubação mineral nitrogenada. Estudou-se o aproveitamento do nitrogênio pela cana-de-açúcar (Saccharum spp.) fertilizada com crotalária júncea (Crotalaria juncea L.) e sulfato de amônio (SA), marcados $\operatorname{com}^{15} \mathrm{~N}$. Foram adicionados 195,8 kg e $70 \mathrm{~kg}$ de $\mathrm{N}$ por hectare, respectivamente, de crotalária júncea e $\mathrm{SA}$, nos seguintes tratamentos: testemunha, sem adubação verde e sem $\mathrm{SA}$; sem adubo verde, com SA- ${ }^{15} \mathrm{~N}$; com adubo verde- ${ }^{15} \mathrm{~N}$ e com SA; com adubo verde- ${ }^{15} \mathrm{~N}$, e sem SA; com adubo verde e com SA- ${ }^{15} \mathrm{~N}$. Foram feitas quatro amostragens de folhas +3 e colhidas plantas de $2 \mathrm{~m}$ de linha da cultura para estimativa da produtividade. Com os resultados dos teores de $\mathrm{N}\left(\mathrm{g} \mathrm{kg}^{-1}\right)$ e da abundância isotópica de $\mathrm{N}\left(\%\right.$ em átomos de $\left.{ }^{15} \mathrm{~N}\right)$ das amostras de folhas +3 e da produtividade da cana-de-açúcar, foram calculados o N-acumulado, nitrogênio na planta proveniente do fertilizante-NPPF $\left(\% \mathrm{e} \mathrm{kg} \mathrm{ha}{ }^{-1}\right)$, e a recuperação percentual do $\mathrm{N}$ do fertilizante $(\% \mathrm{R})$. Foram realizadas análises tecnológicas da cana e calculados o pol (\%) e açúcares totais recuperados. As maiores porcentagens de NPPF foram encontradas após oito meses de plantio da cana para os tratamentos com adubo verde sem N-mineral e adubo verde com N-mineral, respectivamente 15,3 e 18,4\%. A maior recuperação do nitrogênio foi encontrada na colheita, dezoito meses após o plantio, sendo que o tratamento com fertilizante mineral apresentou $34,4 \%$ e na soma $\mathrm{N}$-mineral mais $\mathrm{N}$-adubo verde apresentou $40,0 \%$. Os tratamentos com adubo verde mais N-mineral alteraram atributos do solo e da planta, promovendo aumento nos teores de $\mathrm{Ca}$ e $\mathrm{Mg}$, soma de bases e saturação de bases e $\mathrm{pH}$, com declínio na acidez potencial no solo, bem como aumento nos teores de $\mathrm{Ca}$ e K na parte aérea.

Palavras-chave: Saccharum spp., crotalária júncea, ${ }^{15} \mathrm{~N}$, técnica isotópica

Sci. Agric. (Piracicaba, Braz.), v.62, n.6, p.534-542, Nov./Dec. 2005 


\section{INTRODUCTION}

The green manure fertilization of soil with legumes has been recommended before sugarcane field renovations (Cardoso, 1956). This practice does not imply missing the cropping season and does not interfere with cane sprouting, has relatively low cost, and elicits significant increases in sugarcane and sugar yield during at least two consecutive cuts. Additionally, it protects the soil against erosion and prevents spreading of weeds.

The green manure legume must be incorporated when $50 \%$ of plants are flowering, and sugarcane planting should be done immediately after that operation. In the Central-Southern Region of Brazil, the most commonly used legumes are Crotalaria juncea (sunn hemp), velvet bean, soybean, and peanut. Velvet bean is the most frequently used species in Northeast Brazil.

There have been few studies on the amounts of nutrients supplied to crops by green manures (Muraoka, 1984). The assessments of transformations undergone by nitrogen in the soil-plant system are often impaired by the difficulty to discriminate different sources of the element. By using mineral or organic compounds enriched with ${ }^{15} \mathrm{~N}$, the nitrogen stable isotope, its pathways in the environment can be traced with precision (Smith et al., 1963; Fried et al., 1975). This technique allows precise information to be obtained on the fate of nitrogen in the soil-plant system.

Ambrosano (1995) studied the fate of nitrogen from green manure legumes and found that the efficiency of use of this nitrogen source by corn was $30 \%$, for the above-ground part of sunn hemp incorporated to a podzolic soil. In the study, the legumes were labeled with two atoms $\%$ excess ${ }^{15} \mathrm{~N}$, ensuring excellent experimental results (Ambrosano et al., 1997). Trivelin et al. (1995; 1996) showed sugarcane recovery values of nitrogen applied in mineral form ranging from 19 to $40 \%$.
The objectives of this work were evaluating the utilization by sugarcane of nitrogen from green fertilization and from mineral fertilization with ammonium sulfate, applied together or separately; and evaluating the impact of these $\mathrm{N}$ sources on agricultural productivity, sugar yield, nutrient contents in the plant, and soil chemical characteristics.

\section{MATERIAL AND METHODS}

The experiment was carried out in Piracicaba, SP, Brazil $\left(22^{\circ} 42^{\prime} \mathrm{S}, 47^{\circ} 38^{\prime} \mathrm{W}\right.$; altitude $\left.560 \mathrm{~m}\right)$. The area's soil, classified as Arenic Hapludult, was chemically characterized at different depths after cutting the green manure crop, before planting the sugarcane (Table 1).

In the first stage of the experiment, the sunn hemp was sown and labeled with ${ }^{15} \mathrm{~N}$. The dry, labeled plant material containing 2.412 atoms $\%$ excess ${ }^{15} \mathrm{~N}$ was obtained in December, 2000. Total dry mass was equivalent to $9.150 \mathrm{Mg} \mathrm{ha}^{-1}$, with $21.4 \mathrm{~g} \mathrm{~kg}^{-1} \mathrm{~N}$, totaling and inflow of $195.8 \mathrm{~kg} \mathrm{ha}^{-1} \mathrm{~N}$ added to the soil, as described by Ambrosano et al. (2003). Next, nitrogen utilization by sugarcane fertilized with sunn hemp as a green manure crop (SH) and ammonium sulfate (AS), both labeled with ${ }^{15} \mathrm{~N}$ was assessed. Treatments were: Control; $\mathrm{AS}-{ }^{15} \mathrm{~N}$; SH${ }^{15} \mathrm{~N}+\mathrm{AS} ; \mathrm{SH}_{-}-{ }^{15} \mathrm{~N} ; \mathrm{AS}-{ }^{15} \mathrm{~N}+\mathrm{SH}$

After growing for 90 days, plants were cut and the fresh mass was laid on the soil surface. Sugarcane cultivar IAC- 87-3396 was planted on March 1 $1^{\text {st }}, 2001$. Sidedressing fertilization with ammonium sulfate (AS) was done 90 days from planting. The sidedressing application of mineral ${ }^{15} \mathrm{~N}$ was done using ammonium sulfate labeled with $3.02 \pm 0.01$ atoms $\%{ }^{15} \mathrm{~N}$ (equivalent to 70 $\mathrm{kg} \mathrm{N}$ per hectare).

Experimental plots consisted of 10 sugarcane rows, $10 \mathrm{~m}$ in length, spaced $1.40 \mathrm{~m}$. The ${ }^{15} \mathrm{~N}$-labeled

Table 1 - Soil chemical characteristics before sugarcane planting, in plots with and without green manure, at depths of 0-0.2 and $0.2-0.4 \mathrm{~m}$

\begin{tabular}{|c|c|c|c|c|}
\hline \multirow{2}{*}{ Variables } & \multicolumn{2}{|c|}{ Soil without green manure crop } & \multicolumn{2}{|c|}{ Soil with green manure crop (sunn hemp) } \\
\hline & $0-0.2 \mathrm{~m}$ & $0.2-0.4 \mathrm{~m}$ & $0-0.2 \mathrm{~m}$ & $0.2-0.4 \mathrm{~m}$ \\
\hline $\mathrm{pH}\left(0.01 \mathrm{~mol} \mathrm{H}^{1}\right)$ & 4.1 & 4.0 & 4.5 & 4.7 \\
\hline O.M. $\left(\mathrm{g} \mathrm{dm}^{-3}\right)$ & 26 & 22 & 24 & 22 \\
\hline$P\left(m g d^{-3}\right)$ & 3 & 14 & 6 & 6 \\
\hline $\mathrm{S}\left(\mathrm{mg} \mathrm{dm} \mathrm{m}^{-3}\right)$ & 12 & 15 & 8 & 8 \\
\hline $\mathrm{K}\left(\mathrm{mmol} \mathrm{dm}_{\mathrm{c}}^{-3}\right)$ & 0.7 & 0.5 & 0.3 & 0.3 \\
\hline $\mathrm{Ca}\left(\mathrm{mmol}_{\mathrm{c}} \mathrm{dm}^{-3}\right)$ & 7 & 6 & 12 & 11 \\
\hline $\mathrm{Mg}\left(\mathrm{mmol}_{\mathrm{c}} \mathrm{dm}^{-3}\right)$ & 6 & 5 & 11 & 10 \\
\hline $\mathrm{H}+\mathrm{Al}\left(\mathrm{mmol}_{\mathrm{c}} \mathrm{dm}^{-3}\right)$ & 50 & 68 & 36 & 31 \\
\hline $\mathrm{Al}\left(\mathrm{mmol}_{\mathrm{c}} \mathrm{dm}^{-3}\right)$ & 10 & 11 & 2 & 2 \\
\hline $\mathrm{SB}\left(\mathrm{mmol}_{\mathrm{c}} \mathrm{dm}^{-3}\right)$ & 13.7 & 11.5 & 23.3 & 21.3 \\
\hline $\operatorname{CEC}\left(\mathrm{mmol}_{\mathrm{c}} \mathrm{dm}^{-3}\right)$ & 63.7 & 79.5 & 59.3 & 52.3 \\
\hline $\mathrm{V} \%$ & 22 & 14 & 39 & 41 \\
\hline
\end{tabular}

Sci. Agric. (Piracicaba, Braz.), v.62, n.6, p.534-542, Nov./Dec. 2005 
sources were applied in microplots consisting of three contiguous, 2-m long sugarcane row segments in treatments involving $\mathrm{SH}^{-15} \mathrm{~N}$, and two, 1-m long segments in treatments involving AS $-{ }^{15} \mathrm{~N}$. A basal fertilization containing $100 \mathrm{~kg} \mathrm{ha}^{-1} \mathrm{P}_{2} \mathrm{O}_{5}$ in the form of triple super-phosphate, and $100 \mathrm{~kg} \mathrm{ha}^{-1} \mathrm{~K}_{2} \mathrm{O}$ as potassium chloride, was done in all treatments, to ensure full sugarcane development.

Three complete leaves +3 (3rd auricle visible, according to Kuijper system) were sampled from plants located in the central meter of microplots involving ${ }^{15} \mathrm{~N}$ sources at the positions corresponding to adjacent rows, following the methodology recommended by Trivelin et al. (1994). The samples, collected on 10/29/2001 (1), 02/ 20/2002 (2), and 05/28/2002 (3), were then dried in a forced-air oven at $60^{\circ} \mathrm{C}$, and ground in a Wiley mill. ${ }^{15} \mathrm{~N}$ abundance (atoms \%) and $\mathrm{N}$ content $\left(\mathrm{g} \mathrm{kg}^{-1}\right)$ determinations were made in a Europa Sc. ANCA-SL mass spectrometer coupled to a $\mathrm{N}$ analyzer.

Whole plants were also harvested in all samplings from $2 \mathrm{~m}$ of each treatment in an adjacent area to the microplots, to determine the fresh weight of the above-ground part of the plants. Sub samples taken immediately after grinding samples in a forage mill, were dried in a forced-air oven at $60^{\circ} \mathrm{C}$, and the dry weight determined; nitrogen contents $\left(\mathrm{g} \mathrm{kg}^{-1}\right)$ and ${ }^{15} \mathrm{~N}$ abundance (atoms \%) in the dry samples of plant material from microplots was also determined in a mass spectrometer. The mean mass yield of fresh and dry matter $\left(\mathrm{Mg} \mathrm{ha}^{-1}\right)$ and total cumulative nitrogen $\left(\mathrm{kg} \mathrm{ha}^{-1}\right)$ were estimated for different sampling seasons, as well as $\mathrm{N}$ derived from the labeled source (Ndff) in the aboveground part of sugarcane.

The final sugarcane harvest was done eighteen months after planting, on sampling four. In samplings three $(05 / 28 / 02)$ and four $(08 / 24 / 02)$, the stalks were harvested for technology analyses of Brix \%, pol\%, and total recovered sugar (T.R.S.; $\mathrm{kg}$ per $\mathrm{Mg}$ of sugarcane), in samples consisting of 10 continuous cane stalks in the row, for each treatment (Tanimoto, 1964). Based on data obtained in the technology analysis, agricultural productivity in $\mathrm{Mg}$ of stalk per hectare (TSH; $\mathrm{Mg} \mathrm{ha}^{-1}$ ), total soluble solids (POL \%), and total recovered sugar (T.R.S. per $\mathrm{Mg}$ of cane produced) were calculated.

The percentage and amount of nitrogen in the plant derived from the labeled source (Ndff; \% and $\mathrm{kg}$ $\mathrm{ha}^{-1}$ ), and the $\mathrm{N}$ recovery percentage from the labeled source $(\mathrm{R} \%)$ were calculated based on the isotopic results (atoms \%) from leaf +3 samples in samplings one, two, and three, and stalks in samplings three and four, using the following equations (Trivelin et al., 1994):

$\operatorname{Ndff}(\%)=(a / b) .100$

QNdff $\left(\mathrm{kg} \mathrm{ha}^{-1}\right)=[\operatorname{Ndff}(\%) / 100] . T N\left(\mathrm{~kg} \mathrm{ha}^{-1}\right)$

$\mathrm{R}(\%)=\left[\mathrm{Ndff}\left(\mathrm{kg} \mathrm{ha}^{-1}\right) / \mathrm{NF}\left(\mathrm{kg} \mathrm{ha}^{-1}\right)\right] .100$ where: $\mathrm{a}$ and $\mathrm{b}$ are ${ }^{15} \mathrm{~N}$ abundance values (atoms \% excess) in the plant and in the labeled source (AS or green manure crop), respectively; $\mathrm{TN}$ is total cumulative nitrogen in the sugarcane plant $\left(\mathrm{kg} \mathrm{ha}^{-1}\right)$; NF is the AS-N or green manure-N rate $\left(\mathrm{kg} \mathrm{ha}^{-1}\right)$. For $\mathrm{R} \%$ calculation purposes, rates of $70 \mathrm{~kg} \mathrm{ha}^{-1}$ for $\mathrm{N}$-ammonium sulfate and $195.8 \mathrm{~kg} \mathrm{ha}^{-1} \mathrm{~N}$ for the organic source (sunn hemp) were taken into consideration.

Soil mineral nitrogen (nitrate and ammonium) extracted from a 10 -g soil sample was determined by shaking of the sample with $50 \mathrm{~mL}$ of a $\mathrm{KCl} 2 \mathrm{~mol} \mathrm{~L}^{-1}$ solution. After shaking, the material was filtered and the extract was distilled with $\mathrm{MgO}$ and Devarda's alloy, according to methodology described by Buresh et al. (1982). This procedure was carried out for soil samples collected in each sampling season. Soil samples were also collected for chemical characterization at the sugarcane planting and harvesting seasons.

The chemical analysis of plants to determine macro and micronutrient contents were made in stalks collected in the harvesting season, and followed the method proposed by Bataglia et al. (1983). Precipitation (mm water) and temperature $\left({ }^{\circ} \mathrm{C}\right)$ data were taken along the experimental period from a weather station located at the Pólo Centro Sul, in Piracicaba.

Trials were set up in randomized blocks experimental design, with four treatments $(n=4)$. Treatment means were compared by Tukey test $(\alpha=0.05)$. For the analysis of variance, the $\mathrm{Ca}, \mathrm{Mg}$, and $\mathrm{SB}$ data from the soil sampling made during the planting season, and the $\mathrm{Mg}$ data obtained during the sugarcane harvesting season were transformed to $\log (\mathrm{x})$, since the assumptions of the mathematical model were violated. For mineral $\mathrm{N}$ in the soil, a random blocks design was used, with four replicates organized as split plots, where plots represented treatments and subplots represented depths.

Statistical analysis of other data was performed using the concept of measurements repeated in time and the MIXED procedure in the SAS (Statistical Analysis System) version 8.2 for Windows software (Littel et al., 1996). The AKAIKE information criterion was used to select the variance and covariance matrix, by choosing the matrix with the smallest value for that parameter (Akaike, 1974 and SAS, 2004). In the statistical model, the effects of treatment, sampling seasons, and their interactions were considered fixed, and the block effect was considered random. The adjusted means for the fixed effects were obtained with the "LSMEANS" option, and mean comparisons were made by the Tukey-Kramer test $(\alpha=0.1)$.

\section{RESULTS AND DISCUSSION}

There was an increase in fresh and dry plant matter weight and cumulative nitrogen, in the mean of four samplings, in the treatment consisting of green manure 
crop and mineral nitrogen applied together in relation to the control treatment (Table 2). However, no difference was observed in relation to the other treatments and the control for all parameters listed in Table 2. The fresh and dry matter yields, as well as cumulative $\mathrm{N}$, were significantly higher in the fourth sampling. However, nitrogen contents were significantly smaller, demonstrating the occurrence of a dilution effect of $\mathrm{N}$ in the plant matter produced.

The cumulative $\mathrm{N}$ results are similar to those found by Oliveira (1999), who obtained, during sugar cane harvesting, mean values of $252.3 \mathrm{~kg} \mathrm{ha}^{-1}$ cumulative nitrogen, with high nitrogen and plant material accumulation during the last three months, as also observed by Trivelin et al. (1996). The nitrogen contents found in the above-ground part of sugarcane, (Table 2), are in agreement with results of Oliveira (1999). Significant differences between treatments were only observed in May 28, 2002 sampling, and the treatment containing AS- ${ }^{15} \mathrm{~N}$ was superior to those involving $\mathrm{SH}_{-}{ }^{15} \mathrm{~N}$.

Mascarenhas et al. (1994) provided evidence of the positive effect of green manure fertilization with sunn hemp in sugarcane, with higher productivity than with the application of $40 \mathrm{~kg} \mathrm{ha}^{-1}$ mineral $\mathrm{N}$ to the soil. Kanthack et al. (1991), studying lupine in corn, and Muraoka et al. (2002), studying velvet bean and sunn hemp in rice, did not observe any effect of mineral $\mathrm{N}$ applied together with the green manure crop.

Table 2 - Fresh and dry sugarcane plant matter, nitrogen content, and nitrogen accumulated in the plant in samplings of 29 October 2001 (1), 20 February 2002 (2), 28 May 2002 (3), and 24 August 2002 (4).

\begin{tabular}{|c|c|c|c|c|c|c|}
\hline \multirow{2}{*}{$\begin{array}{l}\text { Sampling } \\
\text { season }\end{array}$} & \multicolumn{6}{|c|}{ Treatments } \\
\hline & Control & AS- ${ }^{15} \mathrm{~N}^{2}$ & $\mathrm{SH}+\mathrm{AS}-{ }^{15} \mathrm{~N}$ & $\mathrm{SH}-{ }^{15} \mathrm{~N}$ & Mean & SEM $^{1}$ \\
\hline & \multicolumn{6}{|c|}{ - } \\
\hline 1 & 7.2 & 9.8 & 13.1 & 12.2 & $10.5 \mathrm{D}$ & 0.79 \\
\hline 2 & 24.9 & 31.2 & 36.3 & 36.4 & $32.2 \mathrm{C}$ & 0.91 \\
\hline 3 & 35.8 & 36.6 & 37.7 & 44.2 & $38.5 \mathrm{~B}$ & 1.71 \\
\hline 4 & 85.9 & 106.2 & 128.7 & 92.4 & $103.3 \mathrm{~A}$ & 4.72 \\
\hline Mean & $38.4 \mathrm{~b}$ & $45.9 \mathrm{ab}$ & $53.9 \mathrm{a}$ & $46.3 \mathrm{ab}$ & & \\
\hline \multirow[t]{2}{*}{ SEM $^{1}$} & 2.40 & 2.40 & 2.40 & 2.40 & & \\
\hline & \multicolumn{6}{|c|}{ 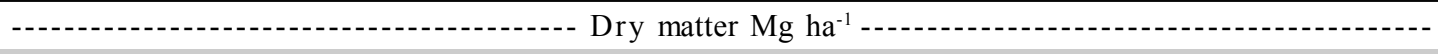 } \\
\hline 1 & 1.9 & 2.4 & 3.2 & 2.9 & $2.6 \mathrm{D}$ & 0.19 \\
\hline 2 & 6.1 & 7.4 & 8.6 & 8.8 & $7.7 \mathrm{C}$ & 0.22 \\
\hline 3 & 11.4 & 10.9 & 11.2 & 13.9 & $11.9 \mathrm{~B}$ & 0.56 \\
\hline 4 & 25.5 & 31.6 & 37.9 & 27.6 & $30.7 \mathrm{~A}$ & 1.47 \\
\hline Mean & $11.2 \mathrm{~b}$ & $13.1 \mathrm{ab}$ & $15.2 \mathrm{a}$ & $13.3 \mathrm{ab}$ & & \\
\hline \multirow[t]{2}{*}{ SEM } & 0.74 & 0.74 & 0.74 & 0.74 & & \\
\hline & \multicolumn{6}{|c|}{ - } \\
\hline 1 & $15.2 \mathrm{~A} \mathrm{a}$ & $15.9 \mathrm{~A} \mathrm{a}$ & $16.3 \mathrm{~A} \mathrm{a}$ & $15.3 \mathrm{~A} \mathrm{a}$ & 15.7 & 0.023 \\
\hline 2 & $13.9 \mathrm{AB}$ a & $14.6 \mathrm{AB}$ a & $14.3 \mathrm{AB}$ a & $12.8 \mathrm{~B} \mathrm{a}$ & 13.9 & 0.023 \\
\hline 3 & $11.5 \mathrm{~B} \mathrm{ab}$ & $12.6 \mathrm{~B} \mathrm{a}$ & $12.1 \mathrm{~B} \mathrm{ab}$ & $10.2 \mathrm{C} \mathrm{b}$ & 11.6 & 0.023 \\
\hline 4 & $6.8 \mathrm{C} \mathrm{a}$ & $7.5 \mathrm{C} \mathrm{a}$ & $6.9 \mathrm{C} \mathrm{a}$ & $8.2 \mathrm{C} \mathrm{a}$ & 7.4 & 0.023 \\
\hline Mean & 11.9 & 12.7 & 12.4 & 11.6 & & \\
\hline \multirow[t]{2}{*}{ SEM } & 0.023 & 0.023 & 0.023 & 0.023 & & \\
\hline & \multicolumn{6}{|c|}{ - Cumulative $\mathrm{N} \mathrm{kg} \mathrm{ha}^{-1}$} \\
\hline 1 & 30.0 & 38.8 & 53.1 & 44.9 & $41.7 \mathrm{D}$ & 3.13 \\
\hline 2 & 84.3 & 108.5 & 123.9 & 112.1 & $107.2 \mathrm{C}$ & 3.36 \\
\hline 3 & 132.6 & 137.6 & 135.3 & 139.3 & $136.2 \mathrm{~B}$ & 5.80 \\
\hline 4 & 177.4 & 235.6 & 256.9 & 220.4 & $222.6 \mathrm{~A}$ & 14.09 \\
\hline Mean & $106.1 \mathrm{~b}$ & $130.1 \mathrm{ab}$ & $142.3 \mathrm{a}$ & $129.2 \mathrm{ab}$ & & \\
\hline SEM & 7.37 & 7.37 & 7.37 & 7.39 & & \\
\hline
\end{tabular}

Means followed by the same lower case letter, in the rows, and upper case letter, in the columns, are not different by the Tukey-Kramer test $(\mathrm{P}>0.10) .{ }^{1}$ Standard error of the mean. ${ }^{2} \mathrm{AS}-{ }^{15} \mathrm{~N}\left({ }^{15} \mathrm{~N}\right.$-labeled ammonium sulfate). SH $+\mathrm{AS}-{ }^{15} \mathrm{~N}$ (Sunn hemp $+{ }^{15} \mathrm{~N}$-labeled ammonium sulfate). $\mathrm{SH}^{-15} \mathrm{~N}\left({ }^{15} \mathrm{~N}\right.$-labeled Sunn hemp). 
The nitrogen contents in sugarcane leaves and stalks derived from labeled sources (Ndff \%), total amount of nitrogen (QNdff in $\mathrm{kg} \mathrm{ha}^{-1}$ ), and nitrogen recovery ( $\mathrm{R} \%$ ) of treatments in different samplings are presented in Tables 3 and 4 . With regard to nitrogen percentages in sugarcane leaves from labeled sources (Table 3), a higher sugarcane nitrogen percentage derived from sunn hemp was observed in the first sampling, which demonstrates the importance of the presence of an organic source for initial nitrogen nutrition in sugarcane. With regard to the amounts of nitrogen found in sugarcane leaves, no differences can be observed between nitrogen supplied by sunn hemp either supplemented or not with mineral $\mathrm{N}$, indicating that both sources were able to supply the crop's nitrogen requirements. Smaller mineral nitrogen recovery was also registered in the first season, compared with nitrogen from sunn hemp, which did not vary with time.

The higher percentage of nitrogen in sugarcane derived from sunn hemp in the first sampling may indicate that, under the low water availability condition to which the crop was submitted (Figure 1), nitrogen was supplied by the organic source, since this value was about three times higher than the mineral source (Table 3). This was not reflected on nitrogen recovery, since no difference due to nitrogen source on the percentage of $\mathrm{N}$ re- covered by sugarcane was observed in the first sampling (Table 3). In later samplings, recovery was higher in mineral $\mathrm{N}$ treatments.

Three months before harvest (Table 4), the percentages of nitrogen in the stalk derived from an organic source were low in sunn hemp treatments, increasing to approximately $8 \%$ in the harvest, and becoming equal to the other treatments that involved mineral N. A greater proportion of nitrogen derived from mineral $\mathrm{N}$ was observed in stalk samplings obtained on May 28, 2002. However, regarding the amount of nitrogen in the stalk from labeled sources, no differences between treatments were observed on average, which indicates an adequate supply of nitrogen to sugarcane from both sources. At harvest, total recovery from stalks $\left(\mathrm{AS}-{ }^{15} \mathrm{~N}+\mathrm{SH}+\mathrm{SH}-\right.$ ${ }^{15} \mathrm{~N}+\mathrm{AS}$ ) was $40.0 \%$ (Table 4 ).

With regard to nitrogen recovered by sugarcane stalks, the relatively low values of about $30 \%$ for mineral $\mathrm{N}$ and $9 \%$ for organic $\mathrm{N}$ agree with results in the literature. Trivelin et al. $(1995 ; 1996)$ found values between 19 and $43 \%$ using the mineral fertilizers Aquammonia and Urea in ratoon cane at the beginning and end of the cropping season. According to these authors, in sugarcane, a large part of cumulative $\mathrm{N}$ may originate from nitrogen biological fixation and from $\mathrm{N}$ mineralized in the soil (native N). Similar results were obtained by Muraoka

Table 3 - Nitrogen in leaves derived from the labeled fertilizer source (Ndff and QNdff) and nitrogen recovery (R) in samplings of 29 October de 2001 (1), 20 February 2002 (2), and 28 May 2002 (3).

\begin{tabular}{|c|c|c|c|c|c|c|}
\hline \multirow{2}{*}{$\begin{array}{l}\text { Sampling } \\
\text { season }\end{array}$} & \multicolumn{6}{|c|}{ Treatments } \\
\hline & $\mathrm{AS}-{ }^{15} \mathrm{~N}^{2}$ & $\mathrm{SH}-{ }^{15} \mathrm{~N}+\mathrm{AS}$ & $\mathrm{SH}-{ }^{15} \mathrm{~N}$ & $\mathrm{AS}-{ }^{15} \mathrm{~N}+\mathrm{SH}$ & Mean & $\mathrm{SEM}^{1}$ \\
\hline & \multicolumn{6}{|c|}{ 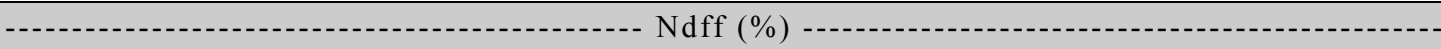 } \\
\hline 1 & $5.0 \mathrm{~B} \mathrm{~b}$ & $18.4 \mathrm{~A} \mathrm{a}$ & $15.3 \mathrm{~A} \mathrm{a}$ & $7.2 \mathrm{~B} \mathrm{~b}$ & 11.5 & 1.89 \\
\hline 2 & $13.1 \mathrm{~A} \mathrm{a}$ & $13.5 \mathrm{AB}$ a & $10.7 \mathrm{AB} \mathrm{a}$ & $15.1 \mathrm{~A} \mathrm{a}$ & 13.1 & 1.44 \\
\hline 3 & $12.0 \mathrm{~A} \mathrm{a}$ & $8.1 \mathrm{~B} \mathrm{a}$ & $7.6 \mathrm{~B} \mathrm{a}$ & $13.2 \mathrm{AB} \mathrm{a}$ & 10.2 & 0.83 \\
\hline Mean & 10.0 & 13.3 & 11.2 & 11.9 & & \\
\hline \multirow[t]{2}{*}{ SEM $^{1}$} & 2.29 & 2.29 & 2.29 & 2.29 & & \\
\hline & \multicolumn{6}{|c|}{ 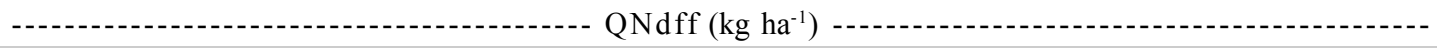 } \\
\hline 1 & 1.9 & 11.2 & 6.9 & 3.6 & $5.9 \mathrm{~B}$ & 1.78 \\
\hline 2 & 14.6 & 16.3 & 12.2 & 24.5 & $16.9 \mathrm{~A}$ & 1.78 \\
\hline 3 & 16.1 & 11.1 & 10.7 & 21.6 & $14.9 \mathrm{~A}$ & 1.78 \\
\hline Mean & $10.9 \mathrm{a}$ & $12.9 \mathrm{a}$ & 9.9 a & $16.6 \mathrm{a}$ & & \\
\hline \multirow[t]{2}{*}{ SEM } & 2.05 & 2.05 & 2.05 & 2.05 & & \\
\hline & \multicolumn{6}{|c|}{ - } \\
\hline 1 & $2.6 \mathrm{~B} \mathrm{a}$ & $5.7 \mathrm{~A} \mathrm{a}$ & $3.5 \mathrm{~A} \mathrm{a}$ & $5.1 \mathrm{~B} \mathrm{a}$ & 4.2 & 0.69 \\
\hline 2 & $20.9 \mathrm{~A} \mathrm{ab}$ & $8.3 \mathrm{~A} \mathrm{ab}$ & $6.3 \mathrm{~A} \mathrm{~b}$ & $35.1 \mathrm{~A} \mathrm{a}$ & 17.7 & 3.07 \\
\hline 3 & $23.0 \mathrm{~A} \mathrm{ab}$ & $5.7 \mathrm{~A} \mathrm{~b}$ & $5.5 \mathrm{~A} \mathrm{~b}$ & $30.9 \mathrm{~A} \mathrm{a}$ & 16.3 & 2.50 \\
\hline Mean & 15.5 & 6.6 & 5.1 & 23.7 & & \\
\hline SEM & 3.08 & 3.08 & 3.08 & 3.08 & & \\
\hline
\end{tabular}

Means followed by the same lower case letter, in the rows, and upper case letter, in the columns, are not different by the Tukey-Kramer test $(P>0.10)$. ${ }^{1}$ Standard error of the mean. ${ }^{2} \mathrm{AS}-{ }^{15} \mathrm{~N}\left({ }^{15} \mathrm{~N}\right.$-labeled ammonium sulfate). $\mathrm{SH}-{ }^{15} \mathrm{~N}+\mathrm{AS}$ ( ${ }^{15} \mathrm{~N}$-labeled Sunn hemp + ammonium sulfate). $\mathrm{SH}-{ }^{15} \mathrm{~N}\left({ }^{15} \mathrm{~N}\right.$-labeled Sunn hemp). AS $-{ }^{15} \mathrm{~N}+\mathrm{SH}\left({ }^{15} \mathrm{~N}\right.$-labeled ammonium sulfate + Sunn hemp). 

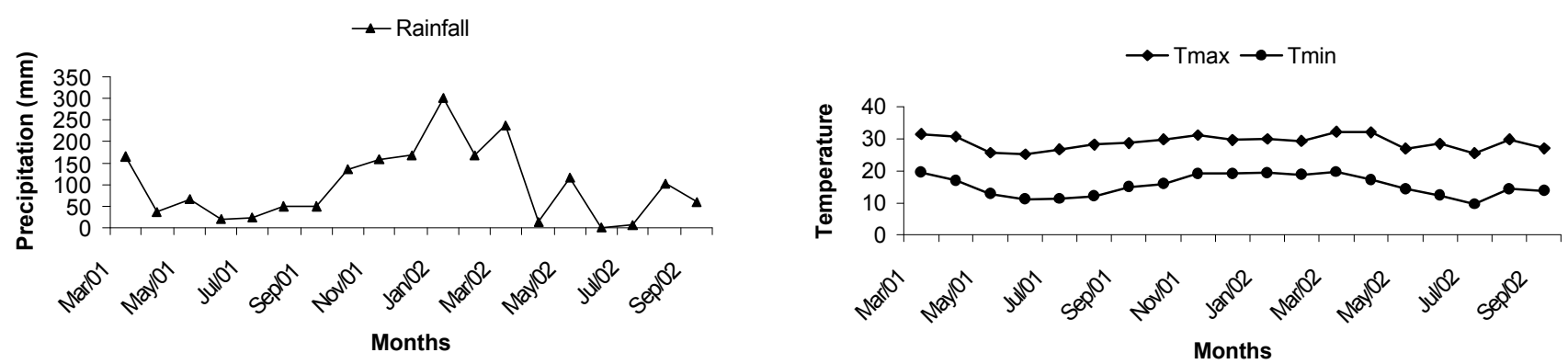

Figure 1 - Climatological data for maximum and minimum temperature and rainfall during the experimental period.

Table 4 - Nitrogen in the stalk derived from the labeled fertilizer source (Ndff and QNdff) and nitrogen recovery (R) in samplings on 28 May 2002 (3) and 24 August 2002 (4).

\begin{tabular}{|c|c|c|c|c|c|c|}
\hline \multirow{2}{*}{$\begin{array}{l}\text { Sampling } \\
\text { season }\end{array}$} & \multicolumn{6}{|c|}{ Treatments } \\
\hline & $\mathrm{AS}-{ }^{15} \mathrm{~N}^{2}$ & $\mathrm{SH}-{ }^{15} \mathrm{~N}+\mathrm{AS}$ & $\mathrm{SH}-{ }^{15} \mathrm{~N}$ & $\mathrm{AS}-{ }^{15} \mathrm{~N}+\mathrm{SH}$ & Mean & SEM $^{1}$ \\
\hline \multicolumn{7}{|c|}{ - } \\
\hline 3 & $14.8 \mathrm{~A} \mathrm{a}$ & $4.0 \mathrm{~A} \mathrm{~b}$ & $3.2 \mathrm{~A} \mathrm{~b}$ & $10.8 \mathrm{~A} \mathrm{a}$ & 8.2 & 0.27 \\
\hline 4 & $10.5 \mathrm{~A} \mathrm{a}$ & $7.0 \mathrm{~A} \mathrm{a}$ & $8.2 \mathrm{~A} \mathrm{a}$ & $10.3 \mathrm{~A} \mathrm{a}$ & 9.0 & 1.12 \\
\hline Mean & 12.7 & 5.5 & 5.7 & 10.6 & & \\
\hline SEM $^{1}$ & 1.13 & 1.13 & 1.13 & 1.13 & & \\
\hline \multicolumn{7}{|c|}{ - } \\
\hline 3 & 4.2 & 0.9 & 0.8 & 3.9 & $2.45 \mathrm{~B}$ & 0.30 \\
\hline 4 & 24.1 & 19.3 & 17.3 & 21.1 & $20.45 \mathrm{~A}$ & 2.83 \\
\hline Média & $14.2 \mathrm{a}$ & $10.1 \mathrm{a}$ & $9.1 \mathrm{a}$ & $12.5 \mathrm{a}$ & & \\
\hline SEM $^{1}$ & 2.77 & 2.77 & 2.77 & 2.77 & & \\
\hline & $\cdots$ & 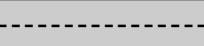 & - & ) & -- & -- \\
\hline 3 & 5.9 & 0.5 & 0.4 & 5.5 & $3.1 \mathrm{~B}$ & 0.41 \\
\hline 4 & 34.4 & 9.9 & 8.8 & 30.1 & $20.8 \mathrm{~A}$ & 3.17 \\
\hline Mean & $20.2 \mathrm{a}$ & $5.2 \mathrm{~b}$ & $4.6 \mathrm{~b}$ & $17.8 \mathrm{a}$ & & \\
\hline SEM $^{1}$ & 3.02 & 3.02 & 3.02 & 3.02 & & \\
\hline
\end{tabular}

Means followed by the same lower case letter, in the rows, and upper case letter, in the columns, are not different by the Tukey-Kramer test $(P>0.10)$. ${ }^{1}$ Standard error of the mean. ${ }^{2} \mathrm{AS}-{ }^{15} \mathrm{~N}\left({ }^{15} \mathrm{~N}\right.$-labeled ammonium sulfate). SH $-{ }^{15} \mathrm{~N}+\mathrm{AS}\left({ }^{15} \mathrm{~N}\right.$-labeled Sunn hemp + ammonium sulfate). SH- ${ }^{15} \mathrm{~N}\left({ }^{15} \mathrm{~N}\right.$-labeled Sunn hemp). AS $-{ }^{15} \mathrm{~N}+\mathrm{SH}\left({ }^{15} \mathrm{~N}\right.$-labeled ammonium sulfate + Sunn hemp).

et al. (2002) using an organic source applied or not together with a mineral source. Two legumes, velvet bean and sunn hemp, and two mineral $\mathrm{N}$ rates, 40 and $80 \mathrm{~kg}$ $\mathrm{N}$ ha ${ }^{-1}$ in the form of urea, were used. The authors concluded that the green manures provided better mineral $\mathrm{N}$ utilization, particularly in sidedressing applications, resulting in an efficiency of use of the source $\mathrm{N}$ of up to $79 \%$.

At the final harvest, there were no differences in the amounts of nitrogen (QNdff) in sugarcane stalks derived from $\mathrm{N}$ sources, indicating that both the organic and the mineral source were able to supply the $\mathrm{N}$ demand by sugarcane, (Table 4). Higher QNdff was also observed during the sugarcane harvest season.

The amount of mineral $\mathrm{N}$ was low in the first sampling (Table 5), a season with great water deficit (sampling on October 29, 2001, eight months after sug- arcane planting), while in the second sampling, made on February 20, 2002 (twelve months after planting), soil mineral $\mathrm{N}$ was significantly higher. There were no differences in soil mineral $\mathrm{N}$ as influenced by the treatments and by collection depth; however, great difference occurred between different sampling seasons, which must be related to the soil moisture (Table 5).

The $\mathrm{SH}+\mathrm{AS}^{-15} \mathrm{~N}$ treatment was prominent in relation to the control, and yielded greater TSH. However, this productivity increase was not reflected on industrial quality, and the treatment showed smaller POL and T.R.S. values at the harvest season (Table 6).

There was no variation in nutrient contents for macronutrients $\mathrm{N}$ and $\mathrm{P}$, and for micronutrients $\mathrm{B}$ and $\mathrm{Zn}$ in sugarcane stalks at harvest (Table 7). However, there were differences in $\mathrm{Ca}$ and $\mathrm{K}$ contents; the latter showed higher values in treatments involving fertilizer applica- 
Table 5 - Soil mineral N at depths of 0-20 and 20-40 cm in samplings of 29 October 2001 (1), 20 February 2002 (2), 28 May 2002 (3), and 24 August 2002 (4).

\begin{tabular}{|c|c|c|c|c|c|c|c|c|c|}
\hline \multicolumn{4}{|c|}{ Treatments } & \multicolumn{2}{|c|}{ Depth (m) } & \multicolumn{4}{|c|}{ Sampling seasons } \\
\hline Control & $A S-{ }^{15} N^{2}$ & $\mathrm{SH}+\mathrm{AS}-{ }^{15} \mathrm{~N}$ & $\mathrm{SH}-{ }^{-15} \mathrm{~N}$ & $0-0.2$ & $0.2-0.4$ & 1 & 2 & 3 & 4 \\
\hline & & & & $\mathrm{ng} \mathrm{kg}{ }^{-1}$ & 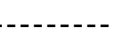 & 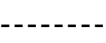 & $\cdots$ & 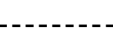 & 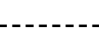 \\
\hline $3.77 \mathrm{a}$ & $4.89 \mathrm{a}$ & $4.12 \mathrm{a}$ & $3.34 \mathrm{a}$ & $4.10 \mathrm{a}$ & $3.95 \mathrm{a}$ & $2.73 \mathrm{~b}$ & $7.46 \mathrm{a}$ & $2.93 \mathrm{~b}$ & $2.99 \mathrm{~b}$ \\
\hline $0.35^{1}$ & 0.35 & 0.35 & 0.35 & 0.20 & 0.20 & 0.31 & 0.31 & 0.31 & 0.31 \\
\hline
\end{tabular}

Means followed by the same letter, for each factor, are not different by Tukey-Kramer test $(P>0.10)$. The interactions between treatment, season, and depth factors were not significant $(P>0.05)$. ${ }^{1}$ Standard error of the mean. ${ }^{2} \mathrm{AS}-{ }^{15} \mathrm{~N}\left({ }^{15} \mathrm{~N}\right.$-labeled ammonium sulfate $)$. SH $+\mathrm{AS}$ $-{ }_{-15} \mathrm{~N}$ (Sunn hemp $+{ }^{15} \mathrm{~N}$-labeled ammonium sulfate). $\mathrm{SH}-{ }^{15} \mathrm{~N}\left({ }^{15} \mathrm{~N}\right.$-labeled Sunn hemp).

Table 6 - Agricultural yield in Mg of stalk (TSH), sugarcane POL \%, and T.R.S., in samplings of 28 May 2002 (3) and 24 August 2002 (4).

\begin{tabular}{|c|c|c|c|c|c|c|}
\hline \multirow{2}{*}{$\begin{array}{l}\text { Sampling } \\
\text { season }\end{array}$} & \multicolumn{6}{|c|}{ Treatments } \\
\hline & Control & AS- $-{ }^{15} \mathrm{~N}^{2}$ & $\mathrm{SH}+\mathrm{AS}-{ }^{15} \mathrm{~N}$ & $\mathrm{SH}-{ }^{15} \mathrm{~N}$ & Mean & SEM $^{1}$ \\
\hline & \multicolumn{6}{|c|}{ - } \\
\hline 3 & 32.5 & 36.6 & 37.7 & 43.3 & $37.5 \mathrm{~B}$ & 1.35 \\
\hline 4 & 85.9 & 106.2 & 128.7 & 92.4 & $103.3 \mathrm{~A}$ & 5.24 \\
\hline Mean & $59.2 \mathrm{~b}$ & $71.4 \mathrm{ab}$ & $83.2 \mathrm{a}$ & $67.9 \mathrm{ab}$ & & \\
\hline \multirow[t]{2}{*}{ SEM $^{1}$} & 4.92 & 4.92 & 4.92 & 4.92 & & \\
\hline & \multicolumn{6}{|c|}{ - } \\
\hline 3 & $12.9 \mathrm{~B} \mathrm{a}$ & $12.5 \mathrm{~B} \mathrm{a}$ & $12.6 \mathrm{~A} \mathrm{a}$ & $12.8 \mathrm{~B} \mathrm{a}$ & 12.7 & 0.15 \\
\hline 4 & $14.2 \mathrm{~A}$ a & $14.1 \mathrm{~A} \mathrm{ab}$ & $12.6 \mathrm{~A} \mathrm{~b}$ & $14.0 \mathrm{~A} \mathrm{ab}$ & 13.7 & 0.15 \\
\hline Mean & 13.6 & 13.3 & 12.6 & 13.4 & & \\
\hline \multirow[t]{2}{*}{ SEM } & 0.22 & 0.22 & 0.22 & 0.22 & & \\
\hline & \multicolumn{6}{|c|}{ - T.R.S. (kg) - } \\
\hline 3 & $127.3 \mathrm{~A} \mathrm{a}$ & $125.1 \mathrm{~B} \mathrm{a}$ & $125.6 \mathrm{~A} \mathrm{a}$ & $126.3 \mathrm{~B} \mathrm{a}$ & 126.1 & 1.29 \\
\hline 4 & $135.1 \mathrm{~A} \mathrm{a}$ & $135.5 \mathrm{~A} \mathrm{a}$ & $122.2 \mathrm{~A} \mathrm{~b}$ & $135.5 \mathrm{~A} \mathrm{a}$ & 132.1 & 1.29 \\
\hline Mean & 131.2 & 130.3 & 123.9 & 130.9 & & \\
\hline SEM & 1.82 & 1.82 & 1.82 & 1.82 & & \\
\hline
\end{tabular}

Means followed by the same lower case letter, in the rows, and upper case letter, in the columns, are not different by the Tukey-Kramer test $(P<0.10)$. ${ }^{1}$ Standard error of the mean. ${ }^{2} \mathrm{AS}-{ }^{15} \mathrm{~N}\left({ }^{15} \mathrm{~N}\right.$-labeled ammonium sulfate). SH $+\mathrm{AS}-{ }^{15} \mathrm{~N}$ (Sunn hemp $+{ }^{15} \mathrm{~N}-$ labeled ammonium sulfate). $\mathrm{SH}-{ }^{15} \mathrm{~N}\left({ }^{15} \mathrm{~N}\right.$-labeled Sunn hemp).

Table 7 - N, K, P, Ca, Zn, and B contents in sugarcane stalks at harvest time.

\begin{tabular}{lcccccc}
\hline \multirow{2}{*}{ Treatment } & $\mathrm{N}$ & $\mathrm{K}$ & $\mathrm{P}$ & $\mathrm{Ca}$ & $\mathrm{Zn}$ & $\mathrm{B}$ \\
\cline { 2 - 7 } & \multicolumn{6}{c}{ Contents determined in sugarcane stalks at harvest } \\
\hline Control & $7.2 \mathrm{a}$ & $3.3 \mathrm{~b}$ & $0.8 \mathrm{a}$ & $1.6 \mathrm{~b}$ & $10.9 \mathrm{a}$ & $12.1 \mathrm{a}$ \\
$\mathrm{AS}-{ }^{15} \mathrm{~N}^{2}$ & $8.1 \mathrm{a}$ & $6.7 \mathrm{a}$ & $0.9 \mathrm{a}$ & $1.7 \mathrm{~b}$ & $15.3 \mathrm{a}$ & $14.9 \mathrm{a}$ \\
$\mathrm{SH}-{ }^{15} \mathrm{~N}$ & $7.7 \mathrm{a}$ & $7.1 \mathrm{a}$ & $0.9 \mathrm{a}$ & $1.8 \mathrm{~b}$ & $13.3 \mathrm{a}$ & $14.8 \mathrm{a}$ \\
$\mathrm{SH}+\mathrm{AS}-{ }^{15} \mathrm{~N}$ & $8.8 \mathrm{a}$ & $8.5 \mathrm{a}$ & $1.0 \mathrm{a}$ & $2.4 \mathrm{a}$ & $13.7 \mathrm{a}$ & $15.4 \mathrm{a}$ \\
Mean & 8.0 & 6.4 & 0.9 & 1.88 & 13.3 & 14.3 \\
\hline C.V. $\%$ & 11.52 & 27.89 & 15.61 & 8.14 & 19.80 & 18.00 \\
\hline
\end{tabular}

Means followed by different letters vertically in each sampling season are different by Tukey test $(P<0.05) .{ }^{2} \mathrm{AS}-{ }^{15} \mathrm{~N}\left({ }^{15} \mathrm{~N}\right.$-labeled ammonium sulfate). SH- ${ }^{15} \mathrm{~N}\left({ }^{15} \mathrm{~N}\right.$-labeled Sunn hemp). SH $+\mathrm{AS}-{ }^{-15} \mathrm{~N}$ (Sunn hemp $+{ }^{15} \mathrm{~N}$-labeled ammonium sulfate).

tion, either mineral or organic, while Ca showed a higher value in the treatment with green manure and mineral $\mathrm{N}$, indicating better nutrition with this element in the treatment containing higher nitrogen supply.
Both $\mathrm{N}$ and $\mathrm{K}$ absorption are greatly influenced by moisture; this relation has been known for a long time (Humbert, 1968), and the fact that treatments involving green manure crops maintained environments with higher 
Table 8 - Chemical characterization of the soil (0-0.2 m depth) in the sugarcane planting and harvesting seasons.

\begin{tabular}{|c|c|c|c|c|c|c|}
\hline \multirow{2}{*}{ Treatment } & \multicolumn{6}{|c|}{ Soil sampling at planting } \\
\hline & $\mathrm{pH}\left(\mathrm{CaCl}_{2}\right)$ & $\mathrm{Ca}$ & $\mathrm{Mg}$ & $\mathrm{H}+\mathrm{Al}$ & SB & $\mathrm{V}$ \\
\hline & $0.01 \mathrm{~mol} \mathrm{l}^{-1}$ & 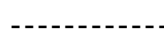 & $-\cdots--m$ & $\mathrm{I}^{-3}-\cdots$ & $-1-1-1$ & $\%$ \\
\hline Control & $5.1 \mathrm{ab}$ & $20.5 \mathrm{ab}$ & $14.5 \mathrm{ab}$ & $37.8 \mathrm{a}$ & $35.4 \mathrm{ab}$ & $48.2 \mathrm{a}$ \\
\hline $\mathrm{AS}-{ }^{15} \mathrm{~N}^{2}$ & $4.7 \mathrm{~b}$ & $15.8 \mathrm{~b}$ & $9.8 \mathrm{~b}$ & $47.0 \mathrm{a}$ & $25.9 \mathrm{~b}$ & $36.0 \mathrm{a}$ \\
\hline $\mathrm{SH}+\mathrm{AS}-{ }^{15} \mathrm{~N}$ & $5.3 \mathrm{a}$ & $24.8 \mathrm{a}$ & $17.8 \mathrm{a}$ & $32.0 \mathrm{a}$ & $42.8 \mathrm{a}$ & $55.8 \mathrm{a}$ \\
\hline $\mathrm{SH}-{ }^{15} \mathrm{~N}$ & $5.0 \mathrm{ab}$ & $18.0 \mathrm{ab}$ & $13.0 \mathrm{ab}$ & $39.0 \mathrm{a}$ & $31.4 \mathrm{ab}$ & $44.5 \mathrm{a}$ \\
\hline Mean & 5.0 & 19.8 & 13.8 & 39.0 & 33.9 & 46.1 \\
\hline \multirow[t]{2}{*}{ C.V.\% } & 5.12 & 7.55 & 10.76 & 20.77 & 6.81 & 22.52 \\
\hline & \multicolumn{6}{|c|}{ Soil sampling at harvest } \\
\hline Control & $5.0 \mathrm{ab}$ & $17.8 \mathrm{a}$ & $14.0 \mathrm{ab}$ & $39.8 \mathrm{ab}$ & $32.2 \mathrm{a}$ & $44.5 \mathrm{ab}$ \\
\hline $\mathrm{AS}-{ }^{15} \mathrm{~N}$ & $4.7 \mathrm{~b}$ & $15.3 \mathrm{a}$ & $9.8 \mathrm{~b}$ & $46.5 \mathrm{a}$ & $25.4 \mathrm{a}$ & $35.8 \mathrm{~b}$ \\
\hline $\mathrm{SH}+\mathrm{AS}-{ }^{15} \mathrm{~N}$ & $5.6 \mathrm{a}$ & $24.7 \mathrm{a}$ & $26.8 \mathrm{a}$ & $25.5 \mathrm{~b}$ & $44.4 \mathrm{a}$ & $67.5 \mathrm{a}$ \\
\hline $\mathrm{SH}-\mathrm{N}$ & $5.0 \mathrm{ab}$ & $19.0 \mathrm{a}$ & $15.3 \mathrm{ab}$ & $36.3 \mathrm{ab}$ & $34.5 \mathrm{a}$ & $48.5 \mathrm{ab}$ \\
\hline Mean & 5.0 & 18.0 & 16.4 & 37.0 & 33.5 & 49.1 \\
\hline C.V.\% & 8.00 & 30.88 & 15.18 & 25.87 & 32.45 & 29.57 \\
\hline
\end{tabular}

Means followed by different letters vertically in each sampling season are different by Tukey test $(P<0.05) .{ }^{2} \mathrm{AS}-{ }^{15} \mathrm{~N}\left({ }^{15} \mathrm{~N}-\mathrm{labeled}\right.$ ammonium sulfate). $\mathrm{SH}+\mathrm{AS}-{ }^{15} \mathrm{~N}$ (Sunn hemp $+{ }^{15} \mathrm{~N}$-labeled ammonium sulfate). $\mathrm{SH}-{ }^{15} \mathrm{~N}$ ( ${ }^{15} \mathrm{~N}$-labeled Sunn hemp).

moisture due to soil mulching with plant mass could have favored better potassium nutrition. With regard to calcium, nitrogen seems to favor absorption (Silva \& Casagrande, 1983).

The presence of a green manure crop and mineral $\mathrm{N}$ applied together caused some soil alterations that could be detected in samples collected in the sugarcane planting and harvesting seasons (Table 8). There was an increase in $\mathrm{Ca}$ and $\mathrm{Mg}$ availability, and consequently in base saturation and $\mathrm{pH}$, in relation to the $\mathrm{AS}-{ }^{15} \mathrm{~N}$ treatment, at planting. Similar results were obtained by Sakai et al. (2003), who worked with four velvet bean cultivars. The presence of green manure caused a significant sum of bases increase, due to increases in calcium and magnesium; consequently, treatments involving velvet bean showed higher CEC values. The presence of organic acids in the plant mass could be the reason for this change (Miyazawa, 2000).

During sugarcane harvest, increases in $\mathrm{Mg}$ concentration, $\mathrm{pH}$, and base saturation $(\mathrm{V} \%)$ were observed in the treatments containing $\mathrm{SH}^{15} \mathrm{~N}+\mathrm{AS}$ in relation to the treatment containing AS $-{ }^{15} \mathrm{~N}$ alone. Also, a significant reduction in potential acidity was observed in treatments containing $\mathrm{SH}-{ }^{15} \mathrm{~N}+\mathrm{AS}$ in relation to the treatment containing $\mathrm{AS}-{ }^{15} \mathrm{~N}$ alone.

\section{ACKNOWLEDGEMENTS}

To Scientific and Technological Research Support Technicians Ângela Maria C. da Silva, Gilberto Farias, Benedito Mota, and Maria Aparecida C. de Godoy. To interns Ana Paula Bueno de Godoy, Rogério Haruo Sakai,
Priscila Helena da Silva, Marcelo Masiero Menuzzo, Áurea Regina Aquino de Souza, and Fernando Augusto Tassani Brefere. To FAPESP and CNPq for support.

\section{REFERENCES}

AKAIKE, $\mathrm{H}$ A new look at the statistical model identification. IEEE Transaction on Automatic Control, v.19, p.716-723, 1974.

AMBROSANO, E.J. Dinâmica do nitrogênio dos adubos verdes crotalária júncea (Crotalaria juncea) e mucuna-preta (Mucuna

aterrima), em dois solos cultivados com milho. Piracicaba: USP/ESALQ, 1995. 83p. (Tese - Doutorado).

AMBROSANO, E.J.; TRIVELIN, P.C.O.; MURAOKA, T. Técnica para marcação dos adubos verdes crotalária júncea e mucuna-preta, com ${ }^{15} \mathrm{~N}$ para estudos de dinâmica do nitrogênio. Bragantia, v.56, p.219-224, 1997.

AMBROSANO, E.J.; TRIVELIN, P.C.O.; CANTARELLA, H.; ROSSETTO, R.; MURAOKA, T.; BENDASSOLLI, J. A.; AMBROSANO, G. M. B.; TAMISO, L. G.; VIEIRA, F.C.; PRADA NETO, I. Nitrogen-15 labeling of Crotalaria juncea Green Manure. Scientia Agricola, v.60, p.181-184, 2003.

BATAGLIA, O.C.; FURLANI, A.M.C.; TEIXEIRA; J.P.F.; FURLANI, P.R.; GALLO, J.R. Métodos de análises químicas de plantas. Campinas: Instituto Agronômico, 1983. 48p. (Boletim Técnico, 78).

BURESH, R.J.; AUSTIN, E.R.; CRASWELL, E.T. Analytical methods in 15N research. Fertilizer Research, v.3, p.337-362, 1982.

CARDOSO, E. Contribuição para o estudo da adubação verde dos canaviais. Piracicaba: USP/ESALQ, 1956. 96p. (Tese - Doutorado).

FRIED, M.; SOPER, R.J.; BROESHART, H. ${ }^{15} \mathrm{~N}$ labelled single-treatment fertility experiments. Agronomy Journal, v. 67, p.393-396, 1975.

HUMBERT, R.P. The growing of sugar cane. Amsterdam: Elsevier, 1968. p.133-309: Nutrition of sugar cane.

KANTHACK, R.A.D.; MASCARENHAS, H.A.A.; CASTRO, O.M. de; TANAKA, R.T. Nitrogênio aplicado em cobertura no milho após tremoço. Pesquisa Agropecuária Brasileira, v.26, p.99-104, 1991.

LITTEL, R.C.; MILLIKEN, G.A.; STROUP, W.W.; WOLFINGER, R.D. SAS System for mixed models. Cary: SAS Institute Inc., 1996. 633p.

MASCARENHAS, H.A.A.; TANAKA, R.T.; COSTA, A.A.; ROSA, F.V.; COSTA, V.F. Efeito residual das leguminosas sobre o rendimento físico e econômico da cana-planta, Campinas: IAC, 1994.15p. (Boletim Científico, 32). 
MIYAZAWA, M.; PAVAN, M.A.; FRANCHINI, J.C. Moléculas orgânicas relacionadas a química e a fertilidade do solo. In: REUNIÃO BRASILEIRA DE FERTILIDADE DO SOLO E NUTRIÇÃO DE PLANTAS - FERTBIO, 24., Santa Maria, 2000. Anais. Santa Maria, 2000. p.1-16.

MURAOKA, T. Utilização de técnicas nucleares nos estudos da adubação verde. In: ENCONTRO SOBRE ADUBAÇÃO VERDE, Rio de Janeiro, 1983. Anais. Campinas: Fundação Cargill, 1984. p.330.

MURAOKA, T.; AMBROSANO, E.J.; ZAPATA, F.; BORTOLETTO, N.; MARTINS, A.L.M.; TRIVELIN, P.C.O.; BOARETTO, A.E.; SCIVITTARO, W.B. Eficiência de abonos verdes (crotalária y mucuna) $\mathrm{y}$ urea, aplicados solo o juntamente, como fuentes de $\mathrm{N}$ para el cultivo de arroz, Terra, v.20, p.17-23, 2002.

OLIVEIRA, M.W. Dinâmica do nitrogênio da uréia $\left({ }^{15} \mathrm{~N}\right)$, no sistema solocana-de-açúcar com e sem queima da palhada. Piracicaba, USP/CENA, 1999. 93p. (Tese - Doutorado).

SAKAI, R.H.; AMBROSANO, E.J.; ROSSETTO, R.; GUIRADO, N.; ARÉVALO, R.A.; CANTARELLA, H.; AMBROSANO, G.M.B.; MENDES, P.C.D.; ROSSI, F.; MOTA, B.; BELIZÁRIO, A.; MARTINELLI, F.; LANZONI, A.C.; SILVA, P. H.; GODOY, A.P.B.; BRÉFERE, F.A.T. Comportamento de quatro cultivares de mucunas em Piracicaba, SP. In: CONGRESSO BRASILEIRO DE CIÊNCIA DO SOLO, 29., Ribeirão Preto, 2003. CD Rom.

SAS Institute. SAS/STAT Software: changes and enhancements through release 8.2. Cary: Statistical System Institute, 2004. 1028p.
SILVA, L.C.F.; CASAGRANDE, J.C. Nutrição mineral da cana-de-açúcar (macronutrientes) In: ORLANDO FILHO, J. Nutrição e adubação da cana-de-açúcar no Brasil. Piracicaba: IAA Planalsucar, 1983. p.77-99.

SMITH, J.H.; LEEG, J.O.; CARTER, J.N. Equipment on ${ }^{15} \mathrm{~N}$ analysis of soil and plant material with the mass spectrometer. Soil Science, v.96, p.313-318, 1963.

TANIMOTO, T. The press method of cane analysis. Hawaiian Planter's Record, Honolulu, v.57, p.133-150, 1964

TRIVELIN, P.C.O.; LARA CABEZAS, W.A.R.; VICTORIA, R.L.; REICHARDT, K. Evaluation of a ${ }^{15} \mathrm{~N}$ plot design for estimating plant recovery of fertilizer nitrogen applied to sugar cane. Scientia Agricola, v.51, p.226-234, 1994.

TRIVELIN, P.C.O.; VICTORIA, R.L.; RODRIGUES, J.C.S. Aproveitamento por soqueira de cana-de-açúcar de final de safra do nitrogênio da aquamônia- ${ }^{15} \mathrm{~N}$ e Uréia $-{ }^{15} \mathrm{~N}$ aplicado ao solo em complemento à vinhaça. Pesquisa Agropecuária Brasileira, v.30, p.1375-1385, 1995.

TRIVELIN, P.C.O.; RODRIGUES, J.C.S.; VICTORIA, R.L. Utilização por soqueira de cana-de-açúcar de inicio de safra do nitrogênio da aquamônia- ${ }^{15} \mathrm{~N}$ e Uréia $-{ }^{15} \mathrm{~N}$ aplicado ao solo em complemento à vinhaça. Pesquisa Agropecuária Brasileira, v. 31, p.89-99, 1996.

Received May 06, 2004

Accepted November 04, 2005 